\title{
The Implementation of Learning Natural Materials Centers in an Effort to Improve Early Chilhood 5-6 Years Science Skills in Kindergarten Al-Azhar Diniyyah Jambi
}

\author{
Sri Mulyati M.Pd ${ }^{1}$ and Dra. Hotma Sumeriwati M.Pd ${ }^{2}$ \\ ${ }^{1}$ Dosen STKIP Al-azhar Diniyyah, Jambi Indonesia \\ ${ }^{2}$ Dosen STKIP Al-azhar Diniyyah, Jambi Indonesia \\ Correspondence email : srimulya4503@gmail.com
}

\begin{abstract}
The purpose of this study is to describe the implementation of learning natural material centers in effort to improve the scientific ability of early childhood aged 5-6 years and also to describe the inhibiting factors for the centers of materials that hinders children's scientific abilities. Research results from the science learning process through the learning strategy of natural based centers can show that there are seven components of the science process which include observing, comparing, classifying, measuring, making simple conclusions as well as predicting and studying natural materials centers that can improve students science ability. To achieve the concept of science as a whole, requires the efforts and competence of teachers in loading aspects of the nature of science in the learning process. One of the main factors is the low understanding of teachers related to early childhood science concept.
\end{abstract}

Keyword: natural materials and science skill early childhood

\begin{abstract}
Abstrak: Tujuan penelitian ini adalah mendeskripsikan pelaksanaan pembelajaran sentra materi alam dalam upaya meningkatkan kemampuan ilmiah PAUD usia 5-6 tahun serta mendeskripsikan faktor penghambat sentra materi yang menghambat kemampuan ilmiah anak. Hasil penelitian dari proses pembelajaran IPA melalui strategi pembelajaran sentra berbasis alam dapat menunjukkan bahwa terdapat tujuh komponen proses pembelajaran IPA yang meliputi mengamati, membandingkan, mengklasifikasi, mengukur, membuat kesimpulan sederhana serta memprediksi dan mempelajari sentra bahan alam yang dapat meningkatkan kemampuan sains siswa. Untuk mencapai konsep IPA secara utuh, diperlukan upaya dan kompetensi guru dalam memuat aspek hakikat IPA dalam proses pembelajaran. Salah satu faktor utamanya adalah rendahnya pemahaman guru terkait konsep IPA PAUD.
\end{abstract}

Kata kunci: materi alam dan keterampilan sains anak usia dini

\section{INTRODUCTION}

Early chilhood is a time for children who are super active love to play and learn and full of creation and imagination. Science skills introduced to children will encourage them to become children who are rich in inspiration. Training children with science experiments can foster logical thinking patterns in to. They will get used to following the stage of science experiments .Thus, children need to be helped to develop science process skills in order to be able to explore and understand the natural surroundings. Based on observation on November, the teacher carried out learning process that was not varied and conventional. The teacher when teaching only used the expository method, meaning that the teacher dominated teaching and learning activities and made students passive. The reality in the field shows that the science learning process only listening process only listens or reads text books. Which is followed by a verbal discussion so that students do find facts and concepts for themselves to acquire knowledge by inquiry. The results of observations of students show that students have scientific abilities are still low. This can be shown from the results of research observations that all science.

Learning models made from natural centers are closely related to improving science skills in children. Because in learning centers made of nature guide children in developing their scientific abilities through material around them such as sticks, sand, water, salt, soil and others. In this study only focused on learning models made from natural centers to improve science skill in children. Because the center made from nature is aimed at providing experiences for children to explore with materials. In this center, children play while learning. To be able to show, recognize, compare, connect and differentiate. By exploring and 
Sri Mulyati and Hotma Sumeriwati, The Implementation of Learning Natural Materials Centers in an Effort to Improve Early Chilhood 5-6 Years Science Skills in Kindergarten Al-Azhar Diniyyah Jambi

experimenting children will have ideas and sensitivity to knowledge and the environment so that the motivation and self confidence in learning grow .Learning center models made from nature are closely related to improving children scientific abilities. Because in learning centers made of natural material around such as stick, sand, water, salt, soil and others. Science can invite children to think critically, because with science children don't just accept or reject something. They observe, analyze, and evaluate existing information before making decision.

By going through scientific experiments through process skills, children can improve their scietific abilities. With observational media, children can find and question objects that they understand. Children aged 4-6 years can be trained. In this way children can be taught basic observation skills such as observation. In this way children can be invited to understand what sound, air, water, light, temperature, soil and various woods and metals Educating children with scientific skills can help parents prevent their children from using inappropriate information. Based on early research science learning in early childhood education is still in the form of concepts and memorization in the form of products such as teaching about the solar system for example: the moon, the stars and others, not teaching process science. It will make children afraid on science and children don't understand. Besides that, science learning is still teacher-centered and not varied so that children's attention becomes unfocused because children are not invited to be directly involved in the science process. This makes children disinterested in learning so that children do not understand science learning. Children scramble to wait their turn to demonstrate the material in this center. It should be by learning science children should be taught how to feel experience and try various natural phenomena. Related to this nature will spur children creativity. Children will also learn to dare to try. a mental trait that is now very valuable which will be useful for children when they growing up. Besides that, doing science experiment is the way to world science.

As the purpose of the learning center such as 1. To improve the service of learning experience to children more deeply by providing freedom of exploration 2. By the center to train children to be more independent because they do not depend on the class teacher alone. But it will be more directed to do activities with other teachers 3.with the center teacher, the center teacher will focus more on developing the center who is responsible for pouring all the development of creative idea.

From the explanation above, the researcher want to know further about the nature center which implemented by Kindergarten Teachers of Diniyyah Al-azhar in Jambi city Improving science ability in children .So that, The researcher interested "The Implementation of learning natural materials centers in an effort to improve early childhood 5-6 years science skills in kindergarten Al-Azhar Diniyyah Jambi.

\section{RELATED THEORIES}

\section{Early Chilhood science learning}

A. Early chilhood science learning as stated by Rosalin and Karen school through college should be viewed more as a verb than a noun. It is not so much a body of knowledge as it is a way of thinking and acting. Science is a way of trying to discover the nature of things that (Rosalin Charlesworth, 1990) (Jo Ann Brewer, 2007). science learning in early chilhood includes activities for to explore the environment and reflect on observation.Spodek states that Science is a system of knowledge about the physical world. It includes ideas about processes, objects, and the relationship among them. In developing concepts, scientis involve themselves in the process of creating knowledge. (Bernard Spodek, 1991). Learning science for early chilhood and the value of science and able to use fundamental aspects in solving problems faced. So, the focus of science learning development program should be aimed at fostering students . understanding, interest and appreciation of the world in which they live.

\section{Center of natural materials}

The center of natural materials is thick with knowledge of science and art. The natural materials center is filled with various natural materials .originating from nature. Children have the opportunity to use play material in various ways according to their thought and ideas with different result. The material needed in this center are leaves, twigs, wood, sand, water, stone and grail. Said the natural material center in sand, 
Sri Mulyati and Hotma Sumeriwati, The Implementation of Learning Natural Materials Centers in an Effort to Improve Early Chilhood 5-6 Years Science Skills in Kindergarten Al-Azhar Diniyyah Jambi

water, stone and grail. Said the natural material center in the center method can be called a sensory center in which it provides method can be called a sensory center in which it provides method can be called a sensory center in which it provides method can be called a sensory center in which it provides method can be called a sensory center in which it provides method can be called a sensory center in which it provides method can be called a sensory center in which it provides method can be called a sensory center in which it provides method can be called a sensory center in which it provides method can be called a sensory center in which it provides method can be called a sensory center in which it provides method can be called a sensory center in which it provides method can be called a sensory center in which it provides. Opportunities for children to be messy play.

According to Latif, natural material centers are provide opportunities for children to interact directly with various kinds of materials to support sensory, self control and science . Natural material centers according to Yudhistira (2021) are places where children can explore with natural materials providing. Opportunities for children to discover knowledge and the concepts about science.

The footing in the learning is 1.) the footing of the playing environment, the footing of the playing environment is called the arrangement of the playing environment in this case the teacher places the tools and playing materials that will be used which reflect the learning plan that has made 2.) the footing before starting game the teacher and children sit in a circle giving greeting to the child.

\section{Theorical Basis}

According to Beijjard (2005), most interpretations of teachers roles refer to teacher's tasks, their social position, status, image and expectations of other people (especially students and parents). Teacher expectation for their role are often associated with the environment and finding a distinction between what actually influenced a particular role the teacher. Day (2006) stated that identity of an individual traditionally consists of roles that are defined through the structure of an individual, institution, and society.

The connection between professional and pedagogical -psychological skills in the role of teacher was also highlighted by Kalin and Steh (2006) stated that preserve teachers not only need the knowledge of their subject, but also a good knowledge of pedagogical knowledge, competence in curriculum design , knowledge and control of didactic procedure of area and knowledge of students.

According to the Regulation of the Minister of National Education, Professional teacher must have four competencies such as: 1 . Professional competence. Professional competence is one of the elements that must be possessed by teachers is by mastering learning materials broadly and deeply, such as academic ability, mastering knowledge, levels and types of education Social competencies that must be possessed by an educator through a good way of communicating with students and all education staff or also with students and all education staff or also with parents or guardians of students 3. Personal competence Personal competence is a personal ability that must be possessed by professional teachers by reflecting a good personality in oneself, being wise and wise, being mature and authoritative and having noble character to be a good role noble.4.Pedagogic competence Pedagogic competence concern the ability of teacher to understand the characteristics or abilities possesses by students in various ways. The main way is to understand students through the development and implementation of learning and evaluating of learning outcomes as well as student development.

In addition to the fourths competition above, in carrying out their duties According to Turney in his book Uzer Usman (2010) suggests that there are eight teaching skills that play a very important and determine the quality of learning.1.Questioning skills, 2. Skill of opening and closing lessons, 3. Skill provide reinforcement, 4.The skill of making variation, 5.Explanatory skills, 6. Skills for guiding small group discussion, 7. Class management skills, 8. Small group and individual teaching skills. Natural-based centers are one of the centers that are applied in early chilhood learning. Natural materials are used to study natural materials such as: sand, water, play dough, colour and other natural centers. 
Sri Mulyati and Hotma Sumeriwati, The Implementation of Learning Natural Materials Centers in an Effort to Improve Early Chilhood 5-6 Years Science Skills in Kindergarten Al-Azhar Diniyyah Jambi

\section{Science skill for early chilhood}

Science learning can be defined as all concrete experimental activities carried out by children in social interactions, contributing to children's interest and slowly emerging understanding of nature , technology , health and physics ( Brostrom,2015).

Trundle \& Sackers (2015) said that Science skill in early chilhood education provides enormous benefit for various aspects of child development, so researchers emphasize how important science learning begin early, science learning for early chilhood can provide positive experiences for children who help themselves to develop an understanding of science concept, develop thinking skill, curiosity, instill positive attitudes influence competence, values, and provide a strong foundation for concept development science in further education ( Eshach \& Fried,2005). The Significance of science education in early chilhood has been widely recognized ( Butzow ,2000). The problem of how scientific concept are obtained plays an important role in the implementation process in the classroom. Where the teacher is able to explain to children the material presented in accordance with scientific concepts.

In relation to early chilhood science learning program . science can be developed into three basic substances. namely education and learning science that facilitates mastery of the science process.

\section{RESEARCH METODE}

This research uses qualitative methods, namely research that produced descriptive data. This research carried out for two months at Diniyyah al azhar jambi. In this research, the researcher act as data collector and as active instruments and collecting data it in the fields.The others data instruments, besides humans there are various tools and several others documents that can support the validity of research results , but only as supporting instruments. Therefore, the presence of researches is directly provided as a measure of the success of understanding research results. This action research plan uses work procedures using two cycles. Data collection techniques are carried out every round since plannning, implementation, observation and reflection for the required data components. Through interviews with teachers . data of the suitability of design of the natural materials center activities with actions by the teacher was obtained through observation .while the school situation data used field notes equipped with videos and photo cameras to documents activities during the research. As for the activities of developing scientific instruments for the age of 5-6 years quantitatively, researches and college of 5-6 years quantitatively, researches and collaboratively determine the criteria for the success of the action in research. Scientific assessment indicators that must be achieved.

Some indicators of science assessment that must be achieved include seven kinds of abilities, namely observing, comparing, classifying, measuring, communicating making simple conclusion and predicting. Each indicator of the science assessment is translated into four rubrics to determine the success score.

\section{THE RESULT AND DISCUSSION}

Based on the research question and the analysis data result, and the results of observation made by researchers that the lack of children's mastery of science because science learning is still not too introduced especially for children. Usually the teacher only provides abstract memorization and children only memorize abstract ones. Children are only used to memorizing but do not participate in interacting with the objects they want to achieve.

Teachers are an important factor in the success of early chilhood science teaching as an effort to help stimulate an environment where programs routinely seek strong evidence to understand what constitute best practice in early chilhood science. Therefore, the number of teaching science in the kindergarten and children's participation in science activities can be important predictors of children's scientific achievement immediately and then because it increase the possibility of children's learning from various basic science concept's and the development of basic science process skills 
Sri Mulyati and Hotma Sumeriwati, The Implementation of Learning Natural Materials Centers in an Effort to Improve Early Chilhood 5-6 Years Science Skills in Kindergarten Al-Azhar Diniyyah Jambi

\section{CONCLUSION}

Research results from the science learning process through the learning strategy of natural -based centers can show that There are seven components of the science process which include observing, comparing, classifying, measuring, making simple conclusions as well as predicting and studying natural materials centers that can improve students' science ability. To achieve the concept of science as a whole, requires the efforts and competence of teachers in loading aspects of the nature of science in the learning process. One of the main factors is the low understanding of teachers related to early childhood science concept.

\section{REFRENCES :}

Abu Ahmadi dan Nur Uhbiyati, 2001, Ilmu Pendidikan, Jakarta : Rineka Cipta

Direktorat Pendidikan Anak Usia Dini. Standart Pendidikan Anak Usia Dini, Jakarta. 2010

Eshach , H.,\& Fried, M. N . (2005). Should science be taught in early chilhood ? Journal for science Education and Technology.

Gelman , R.,\& Brenneman, K . (2004) Science learning pathway for young children . Early chilhood Research Quarterly.

Greenfield, D.B.Jirout ,J., Dominguez (2009). Science in the preschool classroom : A Programmatic research agenda to improve science readness.

Hamzah Uno dan Satria Koni.Assesment Pembelajaran. Jakarta: Bumi Aksara. 2012

Jo Ann Brewer. Introduction to Early Childhood Education Preschool Through Primary

Mulyasa. 2012. Manajemen PAUD. PT. Remaja Rosdakarya. Bandung.

Moeslichatoen. 2004. Metode Pengajaran Di Taman Kanak-kanak. PT Rineka Cipta. Jakarta

Montolalu, B.E.F. 2009. Bermain dan Permainan Anak. Jakarta: Universitas Terbuka

Mulyasa. 2012. Manajemen PAUD. PT. Remaja Rosdakarya. Bandung

Masitoh, Ocih, Heny. 2005. Pendekatan Belajar Aktif Di TK. Jakarta: Diretur Pembinaan Pendidikan Tenaga Kependidikan dan Ketenagaan Perguruan Tinggi.

Mini, R. 2010. Panduan Mengenal dan Mengasah Kecerdasan Majemuk Anak

Rachmawati Yeni, Kurniati Euis. 2010. Strategi Pengembangan Kreativitas Pada Anak Usia Taman Kanakkanak. Kencana Penada Media Group. Jakarta.

Suharsimi, Suhardjono, dan Supardi, Penelitian Tindakan Kelas Jakarta: Bumi Aksara. 2008

Sujiono, Yuliani Nurani. 2008. Metode Pengembangan Kognitif. Jakarta: Universitas Terbuka.

Sumanto. 2005. Pengembangan Kreativitas Seni Rupa Anak TK. Jakarta: Diretur Pembinaan Pendidikan Tenaga Kependidikan dan Ketenagaan Perguruan tinggi.

Suyadi. 2011. Manajemen PAUD. Yogyakarta: Pustaka Pelajar.

Suyanto, S. 2008. Strategi Pendidikan Anak. Yogyakarta: Hikayat.

Yudhistira. (2012). Pendidikan karakter dengan motode sentra. Bekasi: Media Pustaka Sentra 